\title{
PEMBUATAN KARBON AKTIF DARI KULIT SALAK (Salacca Zalacca) DENGAN PROSES FISIKA MENGGUNAKAN UAP DENGAN PEMANAS MICROWAVE
}

\author{
PRODUCTION OF ACTIVATED CARBON FROM ZALACCA PEEL (Salacca Zalacca) \\ BY PHYSICAL PROCESS USING STEAM ASISSTED MICROWAVE HEATING
}

\author{
Indah Sari*, Uchi Inda Purnamasari, M. Turmuzi Lubis \\ Departemen Teknik Kimia, Fakultas Teknik, Universitas Sumatera Utara, \\ Jl. Almamater Kampus USU Medan 20155, Indonesia \\ *Email : indahsarii862@gmail.com
}

\begin{abstract}
Abstrak
Penelitian ini bertujuan untuk menentukan kapasitas adsorpsi terbaik, senyawa yang terkandung pada karbon aktif dan burn off yang dihasilkan. Pada kajian ini, karbon aktif telah disiapkan dari kulit salak dengan aktifasi secara fisika menggunakan microwave. Kulit salak70 gram dipirolisis dalam tungku dialiri gas $\mathrm{N}_{2}$ dengan suhu $500{ }^{\circ} \mathrm{C}$ selama 120 menit diikuti aktivasi menggunakan microwave pada frekuensi $2450 \mathrm{MHz}$ dengan daya $600 \mathrm{~W}, 800 \mathrm{~W}$ dan $1000 \mathrm{~W}$ selama 20 menit, 40 menit dan 60 menit. Hasil penelitian menunjukkan burn off terbaik pada daya microwave $1000 \mathrm{~W}$ dengan waktu aktifasi 60 menit yaitu 90,25\%. Kapasitas adsorpsi karbon aktif terbaik pada daya microwave $800 \mathrm{~W}$ selama 20 menit yaitu $19,96 \mathrm{mg} / \mathrm{g}$. Persentase penyisihan terbaik pada daya $800 \mathrm{~W}$ dengan waktu aktifasi 20 menit yaitu 99,82\%. Karakterisasi Fourier Transform Infra-Red (FITR) menunjukkan adanya ikatan $\mathrm{C}=\mathrm{O}$ (karbonil) yang menunjukkan adanya zat aktif karbon. Setelah pirolisis terbentuk ikatan $\mathrm{C} \equiv \mathrm{C}$ (Alkuna) yang menunjukkan semakin banyak karbon yang dihasilkan. Hal ini didukung oleh karakterisasi Scanning Electron Microscope (SEM) dan Energy Dispersive X-Ray Spectroscopy (EDS) menunjukkan morfologi permukaan dari karbon aktif kasar dan tidak teratur serta besarnya kandungan karbon dan oksida pada karbon aktif sebesar 44,44 $\%$ dan $28,54 \%$ secara berurutan.
\end{abstract}

Kata kunci : Kulit salak, Karbon aktif, Microwave, steam, Metilen blue

\begin{abstract}
This study aimed to determine the best adsorption capacity, compounds contained in activated carbon and burn off that produced. In this study, activated carbon have been prepared from the bark of Salacca zalacca by physically activating using a microwave. The 70 gram bark of Salacca zalaccawas pyrolised in a furnace with flowing gas $\mathrm{N}_{2}$ with temperature $500{ }^{\circ} \mathrm{C}$ for 120 minutes followed by microwave activation at 2450 $\mathrm{MHz}$ with power $600 \mathrm{~W}, 800 \mathrm{~W}$ and $1000 \mathrm{~W}$ for 20 minutes, 40 minutes and 60 minutes. The results showed the best burn off on microwave power $1000 \mathrm{~W}$ with 60 minutes activation time of $90,25 \%$. The best activated carbon adsorption capacity at $800 \mathrm{~W}$ microwave power for 20 minutes is $19,96 \mathrm{mg} / \mathrm{g}$. The best allowanced percentage at $800 \mathrm{~W}$ microwave power with 20 minutes activation time is $99,82 \%$. Characterization of Fourier Transform Infra-Red (FITR) showed the presence of $\mathrm{C}=\mathrm{O}$ (carbonyl) bonds indicating the presence of carbon-active substances. After pyrolysis forms a $\mathrm{C} \equiv \mathrm{C}$ (Alkuna) bond which indicated more carbon was produced. This is supported by the characterization of Scanning Electron Microscope (SEM) and Energy Dispersive X-Ray Spectroscopy (EDS) showing the surface morphology of rough and irregular activated carbon and the amount of carbon and oxide content on activated carbon of $44,44 \%$ and $28,54 \%$ sequentially.
\end{abstract}

Keywords: Activated Carbon, Metylene Blue, Microwave, Skin of Salacca zalacca, Steam

\section{Pendahuluan}

Karbon aktif adalah adsorben yang sangat baik yang telah digunakan ekstensif untuk menghilangkan berbagai polutan, karena memiliki luas permukaan dan porositas yang besar [16]. Karbon aktif juga banyak digunakan dalam pengendalian pencemaran udara, pengolahan makanan, air limbah dan pengobatan [19]. Stuktur pori - pori karbon aktif dapat dilihat selama proses aktifasi. Pada proses aktifasi terjadi reaksi antara char dan aktifator [17].

Pada proses fisika suhu dapat diperoleh dari pemanas konvensional dan pemanas microwave. Karbon aktif yang diproduksi secara konvensional menggunakan uap dan karbon dioksida $\left(\mathrm{CO}_{2}\right)$ maupun campuran uap dan karbon dioksida $\left(\mathrm{CO}_{2}\right)$ [18]. Pemanasan dengan microwave memiliki kelebihan dibandingkan dengan pemanas konvensional karena perpindahan panas yang cepat 
dan efisien, waktu perawatan yang singkat, dan konsumsi energi yang rendah [8].

Salak terdiri dari tiga bagian, yaitu kulit luar, daging buah dan biji. Tekstur kulit buahnya yang bergerigi menyerupai kulit ular sehingga dikenal juga dengan snakefruit. Kulit salak yang masih segar atau yang baru dilepas umumnya mengandung air, karbohidrat, mineral dan protein [5].

Penelitian ini sebagai penelitian pertama pembuatan karbon aktif menggunakan bahan baku kulit salak dengan aktifasi fisika yaitu kombinasi pemanasan konvensional dan microwave yang menggunakan uap sebagai aktifator.

\section{Metodologi Penelitian \\ Bahan dan Alat}

Alat yang digunakan adalah microwave (Teknowell) dengan frekuensi $2450 \mathrm{MHz}$ pada bagian atas microwave dibuat lubang untuk masuk gas nitrogen $\left(\mathrm{N}_{2}\right)$ dan uap sebagai gen aktifator proses fisika dan juga untuk keluaran gas buangan selama proses berlangsung. Selang aliran gas dilengkapi dengan regulator untuk mengatur kecepatan aliran gas nitrogen $\left(\mathrm{N}_{2}\right)$. Uap diperoleh dengan memanaskan aquadest menggunakan setelah itu dialirkan uapnya ke microwave menggunakan selang. Sampel diletakkan di dalam erlenmeyer tepat di bawah aliran gas gas nitrogen $\left(\mathrm{N}_{2}\right)$ dan uap.

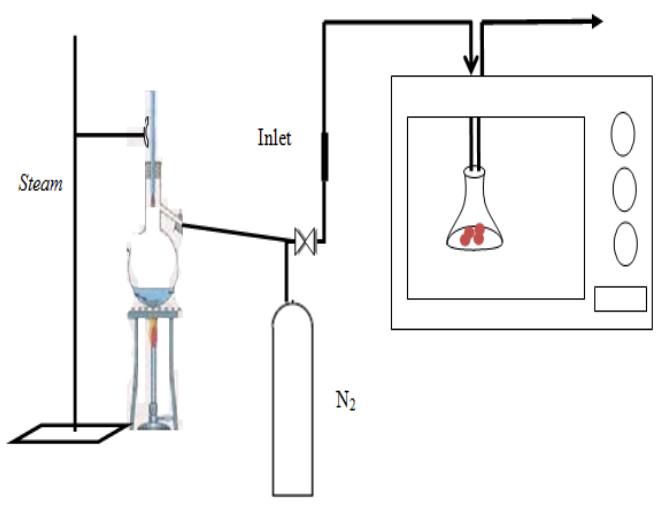

Gambar 1. Rangkaian Alat Pembuatan Karbon Aktif

\section{Proses Pembuatan karbon Aktif}

Pembuatan karbon aktif dari kulit salak menggunakan dua tahap yaitu pirolisis dan aktifasi secara fisika dengan gen pengaktif uap. Kulit salak dicuci dengan air dan kemudian dikeringkan, dan dihaluskan dengan ukuran 32 mesh. Sebanyak 70 gram sampel dimasukan ke dalam tangki pirolisis dengan dialiri gas nitrogen $\left(\mathrm{N}_{2}\right)$ pada laju alir 100 $\mathrm{cm}^{3} /$ min selama 120 menit dengan suhu $500^{\circ} \mathrm{C}$. Sebanyak 20 gram sampel setelah dipirolisis, dimasukkan ke dalam erlenmeyer dengan dialiri uap. Kulit salak diaktifasi dengan variasi daya microwave 600, 800 dan 1000 watt dan variasi waktu 20, 40 dan 60 menit.

\section{Analisis Burn off}

Pada penelitian ini, burn off (kehilangan massa) karbon aktif diperoleh dengan melakukan penimbangan sampel pada awal sebelum proses aktifasi (berat kering sampel mula-mula) dan pada akhir setelah proses aktifasi (berat kering karbon aktif). Adapun persentase burn off dapat ditunjukkan melalui persamaan

Burn off $=\frac{\text { Berat sampel awal }- \text { Berat sampel akhir }}{\text { Berat sampel awal }} \times 100 \%$

\section{Penentuan Daya Serap Metilen Biru}

Dalam penentuan daya serap metilen biru. Sampel ditimbang sebanyak 0,25 gr kemudian dimasukkan ke dalam erelnmeyer dan digunakan untuk adsorbsi metilen biru disertai pengadukan dengan magnetic stirer dengan konsentrasi metilen biru 100 ppm selama 20 menit, kemudian karbon aktif dipisahkan dari larutan metilen biru menggunakan kertas saring. Setelah proses pemisahan, larutan metilen biru (filtrat) kemudian dianalisis kapasitas penyerapan metilen biru. Analisis dilakukan dengan menggunakan spektrofotometer UV-Vis untuk mendapatkan kadar konsntrasi fenol tersisa setelah adsorbsi (C dalam mg/L) dengan spektofotometer. Menghitung kapasitas penyerapan metilen biru yang mana dihitung berdasarkan massa karbon aktif yang teradsorpsi metilen biru

dengan persamaan

$$
\mathrm{q}=\frac{C_{0}-C}{1000} \times V x \frac{1}{B}
$$

Dimana (q) adalah kapasitas penyerapan dalam (mg/g). Co adalah konsentrasi awal metilen biru (mg/L). C adalah konsentrasi akhir metilen biru. V merupakan volume larutan metilen biru dan B merupakan massa karbon aktif sebagai adsorben (gram).

\section{Hasil Dan Pembahasan \\ Burn off Karbon Aktif}

Burn off pada daya microwave $600 \mathrm{~W}, 800$ W, dan $1000 \mathrm{~W}$ selama 20, 40, 60 menit ditunjukkan pada Gambar 1. Pada waktu aktivasi 60 menit mengalami peningkatan yang signifikan diandingkan dengan waktu aktivasi 20 menit dan 40 menit. Persentase burn off tertinggi diperoleh pada daya microwave $1000 \mathrm{~W}$ selama 60 menit sebesar $90,25 \%$. Sedangkan terendah pada daya microwave 600 watt selama 20 menit sebesar $29,10 \%$. 


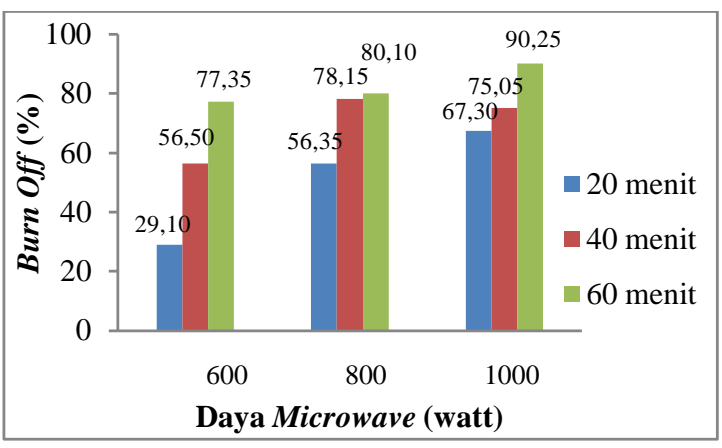

Gambar 1 Pengaruh Daya Microwave terhadap Burn off

Hasil penelitian menunjukkan bahwa burn-off karbon aktif yang dihasilkan dengan daya microwave 600, 800 dan 1000 Watt dengan waktu 20, 40 dan 60 menit meningkat seiring dengan meningkatnya daya microwave. Peningkatan nilai burn-off dikarenakan ketika daya microwave mencapai tingkat tinggi, energi yang berlebih dapat menyebabkan kuantitas karbon aktif yang terbakar semakin kecil dan struktur pori mengalami kerusakan [6]. Selain itu peningkatan daya microwave menyebabkan hilangnya material volatil dalam bahan. Sehingga meningkatkan persentase burn-off [1].

Pengaruh Daya Microwave Terhadap Kapasitas Penjerapan Metilen Biru

Pengaruh daya microwave dan waktu aktivasi terhadap kapasitas penjerapan metilen biru dapat dilihat pada Gambar 2.

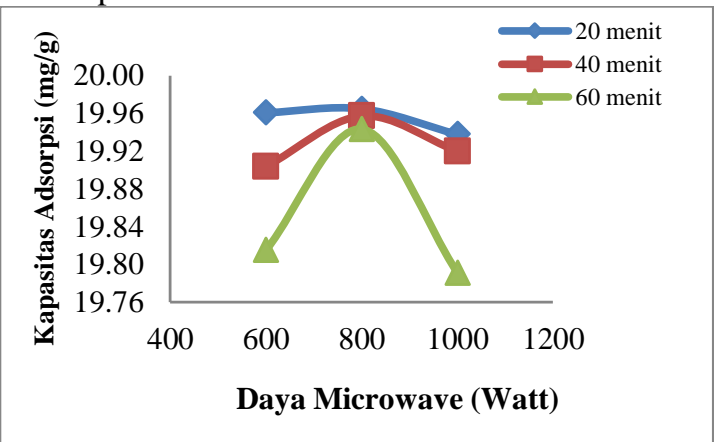

Gambar 2. Pengaruh Daya terhadap Kapasitas Penyerapan

Hasil analisa menunjukkan kapasitas penyerapan metilen biru meningkat seiring dengan meningkatnya daya microwave. Pada daya microwave 600 watt sampai 800 watt, kapasitas penyerapan metilen biru meningkat dan menurun setelah mencapai daya microwave 1000 watt. Hal ini disebabkan oleh daya microwave yang tinggi menghasilkan derajat aktifsi yang tinggi sehingga proses pembentukan pori menjadi lebih baik [14]. Namun, pada penelitian ini kapasitas penjerapan ada yang menurun. Hal ini mungkin disebabkan karena daya microwave yang tinggi terjadi penyusutan pada char dan penataan kembali stuktur karbon yang mengakibatkan berkurangnya luas area pori [1]. Energi yang berlebih juga dapat menyebabkan penghancuran struktur yang berlebih sehingga terjadi kerusakan pada pori karbon aktif $[2,13]$. Kerusakan struktur pori ini menimbulkan kerugian pada pengurangan luas permukaan dan porositas sehingga kapasitas adsorpsi karbon aktif menurun [9].

\section{Analisis Morfologi Permukaan Karbon Aktif}

Analisis dilakukan pada karbon aktif yang memiliki bilangan $u v$-vis tertinggi dan hasilnya dapat dilihat pada Gambar 3.

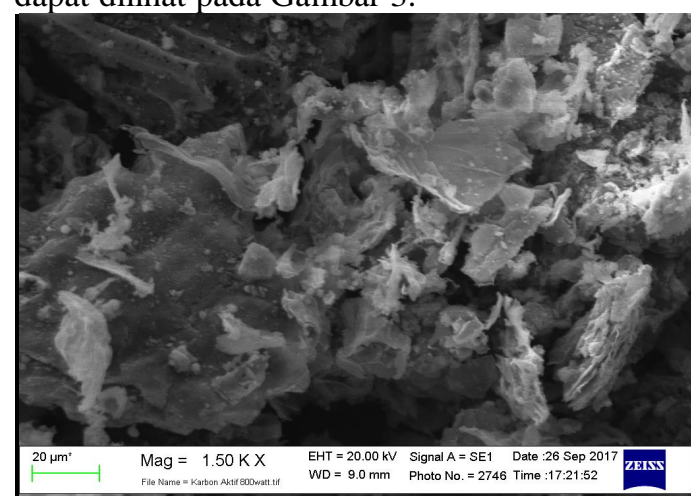

Gambar 3. Hasil Scanning Electron Microscophys (SEM) Karbon Aktif dengan Perbesaran 1500x.

Gambar 3 terlihat hasil SEM morfologi permukaan dari karbon aktif kulit salak menunjukkan permukaan pori yang kasar dan tidak teratur yang tersebar di seluruh karbon aktif. Proses aktifasi bertujuan untuk memperbesar pori yaitu dengan cara memecahkan ikatan hidrokarbon atau mengoksidasi molekul-molekul permukaan sehingga arang mengalami perubahan yaitu luas permukaannya bertambah besar dan berpengaruh terhadap daya adsorpsi [4].

\section{Analisis Gugus Fungsi Karbon Aktif}

Analisis Fourier Transform Infra Red (FTIR) ini ditujukan untuk melihat gugus fungsi dan perubahan gugus fungsi dari bahan ataupun senyawa yang digunakan. Dalam penelitian ini dilakukan uji FTIR untuk melihat perubahan gugus fungsi kulit salak, setelah pirolisis dan setelah aktivasi pada kondisi operasi diperoleh bilangan metilen biru yang paling tinggi dapat dilihat pada Gambar 4. 


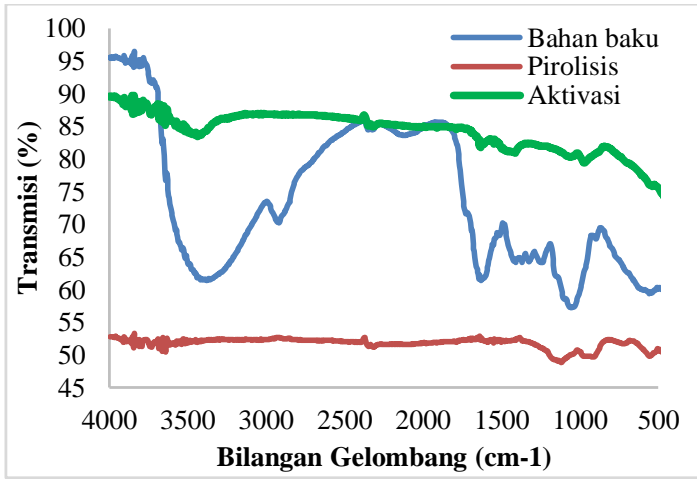

Gambar 4. Hasil Fourier Transform Infrared pada Bahan Baku Kulit Salak, karbon aktif Setelah Dipirolisis dan Setelah Diaktifasi

Puncak serapan kulit salak sebelum pirolisis menunjukkan pita serapan yang lebar dan kuat pada daerah serapan $3394,72 \mathrm{~cm}^{-1}$, sedangkan setelah pirolisis gelombang ini naik menjadi $3417,86 \mathrm{~cm}^{-1}$ dan setelah aktivasi bilangan gelombang menjadi $3437,15 \mathrm{~cm}^{-1}$. Puncak serapan pada bilangan 3600$3200 \mathrm{~cm}^{-1}$ (merujuk pada $\mathrm{O}-\mathrm{H}$ stretching) mengindikasikan adanya gugus fungsi $\mathrm{O}-\mathrm{H}$ (hidroksil) [15]. Dari hasil yang diperoleh terjadi kenaikan puncak serapan, hal ini karena penguraian gugus $\mathrm{OH}$ pada holoselulosa maupun lignin kulit salak. Peningkatan suhu saat karbonisasi menyebabkan gugus $\mathrm{OH}$ terurai membentuk struktur baru yaitu rantai karbon. Besarnya gugus hidroksil merupakan cerminan dari banyaknya senyawa kimia pada kulit salak yang mengandung gugus $\mathrm{OH}$ seperti senyawa alkohol dan fenol [12]. Kenaikan puncak serapan merupakan petunjuk mulai terbentuknya senyawa aromatik yang merupakan unsur penyusun karbon aktif [10].

Pada spektrum gelombang FTIR sebelum pirolisis bilangan gelombang $1624,06 \mathrm{~cm}^{-1}$. Namun bilangan ini hilang setelah dipirolisis dan muncul kembali setelah karbon aktif telah diaktivasi dengan bilangan gelombang $1627,92 \mathrm{~cm}^{-1}$. Puncak serapan pada bilangan gelombang 1600-1800 $\mathrm{cm}^{-1}$ mengindikasikan keberadaan gugus $\mathrm{C}=\mathrm{O}$. Gugus $\mathrm{C}=\mathrm{O}$ merupakan gugus khas yang terdapat pada karbon aktif dan menunjukkan bahwa kulit salak membentuk zat aktif karbon. Hasil aktivasi menunjukkan serapan tajam dan intensitas lemah di bilangan gelombang $1234,44 \mathrm{~cm}^{-1}$. Puncak serapan pada bilangan $1300-1000 \mathrm{~cm}^{-1}$ mengidentifikasi gugus $\mathrm{C}-\mathrm{O}$ [13]. Keberadaan gugus C-O menunjukkan adanya ikatan $\mathrm{C}=\mathrm{O}$ tidak stabil.

Proses aktivasi juga telah membentuk ikatan $\mathrm{C}=\mathrm{C}$ yang ditandai dengan adanya pemunculan spektrum pada bilangan gelombang $1423,47 \mathrm{~cm}^{-1}$. Puncak serapan pada bilangan $1500-1400 \mathrm{~cm}^{-1}$ mengindikasikan keberadaan gugus $\mathrm{C}=\mathrm{C}$. Gugus $\mathrm{C}=\mathrm{C}$ menunjukkan adanya peningkatan kadar karbon [7]. Spektrum gelombang menunjukkan bahwa sebelum pirolisis, setelah pirolisis dan aktivasi, kulit salak memiiki gugus yang sama yaitu $\mathrm{C}-\mathrm{H}$ (aromatis) pada bilangan gelombang dibawah $900 \mathrm{~cm}^{-1}$ [3] dimana spektrum gelombang paling tinggi pada $887,26 \mathrm{~cm}^{-1}$ yaitu sampel hasil pirolisis. Gugus fungsi yang terdapat pada karbon aktif kulit salak yaitu gugus $\mathrm{C}=\mathrm{O}, \mathrm{C}=\mathrm{C}, \mathrm{C}-\mathrm{C}$ dan $\mathrm{C}-\mathrm{H}$.

\section{Kesimpulan}

Kesimpulan yang dapat diambil dari penelitian ini adalah:

1. Persentase burn off tertinggi pada daya microwave 1000 watt dengan waktu aktivasi 60 menit yaitu 90,25\%.

2. Kapasitas adsorpsi metilen biru tertinggi adalah $19,96 \mathrm{mg} / \mathrm{g}$ yang diperoleh pada daya microwave 800 watt dengan waktu aktivasi 20 menit.

3. Hasil spektofotometri Fourier Transform InfraRed (FTIR) mengandung gugus fungs $\mathrm{O}-\mathrm{H}$ (Hidroksil), C-H (Alifatik), C-C , C=O , C=C pada karbon aktif

4. Hasil karakterisasi Energy Dispersive X-Ray Spectroscopy (EDS) terlihat karbon aktif mengandung unsur $\mathrm{C}, \mathrm{O}, \mathrm{K}, \mathrm{Ca}, \mathrm{P}$ dan $\mathrm{Mg}$ berturut-turut sebesar 44,44\%; 28,54\%; $11,31 \% ; 6,10 \% ; 1,73 \%$; dan $4,53 \%$.

\section{Daftar Pustaka}

[1] A. Abbas, Muthanna J. Ahmed. 2014, Optimization of Activated Carbon Preparation from Date Stones by Microwave Assisted $\mathrm{K}_{2} \mathrm{CO}_{3}$ Activation, Iraqi Journal of Chemical and Petroleum Engineering, Vol. 15, No. 1, ISSN 1997-4884.

[2] E. Ebere M, Ejikeme Patrick C.N, Echegi, U.S.C, 2015, Effcet of Microwave Activation on The Removal Efficiency of Hamburger Seed Shell, Journal of Multidisciplinary Engineering Science and Technology, Vol. 2, Issue 11, ISSN 3159-0040.

[3] G. L, Y. Ladino, J.C M. Pirajanc, M. O. Rodriguez, 2007, Synthesis and Characterization of Activated Carbon Fibers from Kevlar, Ecletica Quimica Vol. 34, No. 4.

[4] H.Singgih dan Ratnawati, 2010, Pembuatan Karbon Aktif dari Tempurung Kelapa Sawit dengan Metode Aktivasai Kimia, Indonesian Journal of Materials Science, Vol. 12, No 1. ISSN : 1411-1098.

[5] H. Zulfi dan Retno Arianingrum, 2010, Pengembangan Tekonologi Pengawetan Kulit Salak Untuk Bahan Produk Seni Kerajinan. Jurnal Penelitian Saintek, Vol. 15, No. 2.

[6] H. Deng, Le Yang, Guanghui Tao, dan Jiulei Dai, 2009, Preparation and Characterization of Activated Carbon from Cotton Stalk by Microwave Assisted Chemical Chemical 
Activation-Application in Methylene Blue Adsorption from Aqueous Solution, Journal of Hazardous Materials.

[7] J. Mohammed, Noor S.Nasri, Muhammad A.A Zaini, Usman D, Hamza.Husna, M. Zaindan, Faridnasir Arif, 2015, Optimization Of Microwave Irradiated - Coconut Shell Activated Carbon Using Response Surface Methodology For Adsorption Of Benzene And Toluene, Article Desalination and Water Treatment.

[8] L. Wei, Jinhui Peng, Libo Zhang, Kunbin Yang, Honying Xia, Shimin Zhang, Sheng-hui Guo, 2010, Preparation of activated carbon from coconut shell chars in pilot-scale microwave heating equiment at $60 \mathrm{Kw}$, Waste Management 29 (2009) 756-760.

[9] M.A. Elsayed dan O.A. Zalat, 2015, Factor Affecting Microwave Assisted Preparation of Activated Carbon from Local Raw Materials, International Letters of Chemistry Physics and Astronomy, ISSN 2299-3843.

[10] M. Menéndez, A. Arenillas, B. Fidalgo, Y. Fernández, L.Zubizarreta, E.G. Calvo, J.M. Bermúdez, 2010, Microwave heating process esinvolving carbon materials, Journal Fuel Processing Technology, Vol . 91 (2010): 1-8.

[11] R. Hoseinzadeh Hesas, Arash Arami Niya, Wan Mohd, Ashri Wan Daud, dan J.N, Sah, 2013, Preparation and Characterization af Activated Carbon from Apple Waste by Microwave Assisted Phosphoric Acid Activation, Application in Methylene Blue Adsorption, Bioresources.

[12] S. Caroline, Matthew A, Adebayo, Eder C. Lima, Renato Cataluna PascalS. Thue, Lizie D.T. Prola, M.J. Puchana-Rosero, Fernando M. Machado, FlavioA, Pavan, G.L. Dotto, 2015, Microwave-Assisted Activated Carbon From Cocoa Shell as Adsorbent For Removal of Sodium Diclofenac and Nimesulide FromAqueous Effluents, Journal of Hazardous Materials, Vol. 289 (2015).

[13] S. Mohammad Saleh, Wan MohdAshri Wan Daud, Amir hossein, Housh manddan, Ahmad Shamiri, A Review On Surface Modification Of Activated Carbon For Carbon Dioxide Adsorption, Journal of Analytical and Applied Pyrolysis 89 (2010).

[14] T. Abbas Sabah, Mustafa M, Al-Faize, dan A.Z Raheem, 2013, Adsorption of $\mathrm{Pb}^{+2}$ and $\mathrm{Zn}^{+2}$ Ions From Oil Wells Onto Activated Carbon Produced From Rice Husk In Batch Adsorption Process, Journal Of Chemical and Pharmaceutical Research, ISSN : 0975-7384.

[15] T. Vasilia, Alina Matei, dan Andrei Marius Avram, 2016, FTIR Spectroscopy for Carbon
Family Study, Critical Reviews in Analytical Chemistry, 46:6.

[16] U. Rivera. M, Sanchez-Polo, V. GomezSerrano, P.M. Alvarez, M.C.M. Alvim-Ferraz, dan J.M. Dias, 2011, Activated Carbon Modifications to Enhance Its Water Treatment Applications An Overview, Journal Of Hazarrdous Materials.

[17] W. Jufang. 2004, Modelin Adsorption Of Organic Compounds on Activated Carbon, Departement Of Chemistry, Umea University.

[18] Y. Kunbin., Jinhui Peng, C. Srinivasakannan, Libo Zhang, Hongying Xia, Xinhui Dua, 2010. Preparation of High Surface Area Activated Carbon From Coconut Shell Using Microwave Heating, Bioresource Technology.

[19] Z. Zhuo, Qi Yang, Xiao-Ming Li, Kun Luo, Guang-Ming Zeng, 2012, Preaparaton Of Peanut Hull- Based Actvated Carbon By Microwave Induced Phosphoric Acd Activation and Its Applications In Remazol Brilliant Blue R Adsorption. Industrial Crops and Products. 